Polish Journal of Microbiology

2011, Vol. 60, No 2, 105-112

ORGINAL PAPER

\title{
Immobilized Cells of Recombinant Escherichia coli Strain for Continuous Production of L-aspartic Acid
}

\author{
GRAŻYNA SZYMAŃSKA*, BOGUSŁAW SOBIERAJSKI and ALEKSANDER CHMIEL
}

Department of Biosynthesis of Drugs, Chair of Biology and Pharmaceutical Biotechnology, Medical University of Łódź, Poland

Received 6 September 2010, revised 15 February 2011, accepted 20 February 2011

Abstract

For L-aspartic acid biosynthesis, high production cells of Escherichia coli mutant B-715 and P1 were immobilized in chitosan gel using a technique developed in our laboratory. The immobilization process reduced initial activity of the intact cells, however, the biocatalyst produced was very stabile for long-term use in multi-repeated batch or continuous processes. Temperature influence on the conversion of ammonium fumarate to L-aspartic acid was investigated. In long-term experiments, over 603 hours, the temperature $40^{\circ} \mathrm{C}$ was found to be the best for both biocatalyst stability and high conversion rate. The optimum substrate concentration was $1.0 \mathrm{M}$. Continuous production of $\mathrm{L}$-aspartic acid was investigated in three types of column bioreactors characterized by different volumes as well as different high to biocatalyst bed volume rations $\left(\mathrm{H}_{\mathrm{z}} / \mathrm{V}_{\mathrm{z}}\right)$. The highest conversion rate, $99.8 \%$, and the productivity $6 \mathrm{~g} / \mathrm{g} / \mathrm{h}$ (mass of L-aspartic acid per dry mass of cells in biocatalyst per time unit) was achieved in the bioreactor with the highest value $\mathrm{H}_{\mathrm{z}} / \mathrm{V}_{\mathrm{z}}=3.1$, and liquid hour space velocity value of 5.2, defined as the volume of feeding substrate passed per volume of catalyst in bioreactor per one hour.

Ke y words: E. coli, immobilized cells, L-aspartic acid

\section{Introduction}

When extracted from cells, intracellular enzymes can be used in solution for only one batch process if they are not immobilized. This shortcoming can be eliminated by enzyme immobilization; however, such preparations are frequently not sufficiently stable and their productivity is usually unsatisfactory for industrial purposes. These disadvantages can be overcome by immobilization of whole cells, enabling both cheaper and less laborious biotechnology to be developed. In their first technological description (Chibata et al., 1974) examined various methods for the immobilization of E. coli cells with high aspartase activity. As a result, L-aspartic acid production on an industrial scale using Escherichia coli cells immobilized in polyacrylamide was developed in 1973 (Chibata et al., 1974). Subsequently, various other polymers for this process have been proposed and applied (Chibata et al., 1985, Fusee et al.,1981); however, it is obvious that continuous improvement of both the biological agents and process technology is necessary. We have previously described our investigations on strain improvement (Gadomska et al., 2007; Papierz et al., 2007) and in this paper, we present our own immobilization method of whole E. coli cells in chitosan for L-aspartic acid biosynthesis in continuous process in column bioreactors.
For industrial production of L-aspartic acid, column bioreactors, single or in combination of two or more columns, are proposed (Lee and Hong, 1988; Tosa et al., 1973; Kawabata et al., 1990; Sato et al., 1975). Continuous L-aspartic acid biosynthesis is carried out using immobilized cells of bacteria with high aspartase activity by passing an ammonium fumarate solution through the biocatalyst bed. Bioreactor productivity is closely related to aspartase activity, ammonium fumarate solution concentration and substrate flow rate. L-aspartic acid biosynthesis is profitable if the conversion rate of ammonium fumarate to the product is over 90\% (Mukouyama et al., 2000; Mukouyama and Komatsuzaki, 2001). In this paper, the continuous process of L-aspartic acid production in column bioreactors was optimized using immobilized cells of recombinant strain Escherichia coli P1.

\section{Experimental}

Materials and Methods

Bacteria. For preliminary elaboration of cell immobilization procedure E. coli mutant B-715 (Papierz et al., 2007) was applied. For continuous process investigations in bioreactors a recombinant strain of E. coli P1

* Corresponding author: G. Szymańska, Department of Biosynthesis of Drugs, Chair of Biology and Pharmaceutical Biotechnology, Medical University of Łódź; ul. Muszyńskiego 1, 90-151 Łódź, Poland; e-mail: grazyna.szymanska@umed.lodz.pl 
(Gadomska et al., 2007) with high aspartase activity was used. The bacterial suspension in LB-medium was mixed with $50 \%$ glycerol (1:1), frozen and stored at $-70^{\circ} \mathrm{C}$ as stocks for further use.

Media (as described earlier, Gadomska et al., 2007). (1) FF medium for biomass cultivation: Yeast Extract (Difco) $20 \mathrm{~g} / \mathrm{l}$, ammonium fumarate $5.0 \mathrm{~g} / \mathrm{l}, \mathrm{KH}_{2} \mathrm{PO}_{4}$ $11.4 \mathrm{~g} / \mathrm{l}, \mathrm{MgSO}_{4} \times 7 \mathrm{H}_{2} \mathrm{O} 0.5 \mathrm{~g} / \mathrm{l}, \mathrm{pH}$ 7.2. (2) Medium for cell activation (activation medium): ammonium fumarate $50.0 \mathrm{~g} / \mathrm{l}, \mathrm{MgSO}_{4} \times 7 \mathrm{H}_{2} \mathrm{O} 0.25 \mathrm{~g} / \mathrm{l}, 1 \%$ Triton $0.5 \mathrm{ml} / \mathrm{l}, \mathrm{pH}$ 8.5. (3) Medium for L-aspartic acid production (productive medium): ammonium fumarate $150.0 \mathrm{~g} / \mathrm{l}, \mathrm{MgSO}_{4} \times 7 \mathrm{H}_{2} \mathrm{O} 0.25 \mathrm{~g} / \mathrm{l}, \mathrm{pH}$ 8.5. Chemicals (at analytical grade), if not indicated otherwise, were purchased from POCh S.A.

Cell multiplication and activation. Bacteria were cultured in shaking flasks as described earlier (Gadomska et al., 2007), then the cells were centrifuged at $4000 \mathrm{rpm}$ for $20 \mathrm{~min}$ and introduced into the activation medium ( $1 \mathrm{~g}$ of wet mass $/ 20 \mathrm{ml}$ ). The cell suspension was activated by shaking for 24 hours in shaking flasks at $37^{\circ} \mathrm{C}$. Activated cells were centrifuged at $4000 \mathrm{rpm}$ for $20 \mathrm{~min}$ and washed twice with distilled water $(1 \mathrm{~g}$ wet mass $/ 20 \mathrm{ml}$ water).

Immobilization of $E$. coli cells with chitosan. Activated cells of $E$. coli were suspended in weight proportion 1:1 in a solution of chitosan consisting of $5.0 \mathrm{~g}$ of chitosan (Marine Institute, Gdynia) dissolved in $100 \mathrm{ml}$ of $2 \%$ acetic acid (Chemical Company of Lublin) and stored for approximately 20 hours at ambient temperature. The mixture was instilled into crosslinking reagent via syringe. Sodium hexametaphosphate $\left(\mathrm{NaPO}_{3}\right)_{12-13} \mathrm{Na}_{2} \mathrm{O}$ (Fluka), sodium ortophosphate (POCh) and penta-sodium triphosphate $\mathrm{Na}_{5} \mathrm{P}_{3} \mathrm{O}_{10}$ (Fluka) were used in different concentrations as crosslinking reagents. The immobilisation process was optimized in this study. After 15-45 min of hardening, the gel pellets obtained were washed with distilled water and placed into the activation medium.

\section{L-aspartic acid biosynthesis}

Process with cell suspension. Activated cells were mixed with the production medium ( 1 g wet mass $/ 20 \mathrm{ml}$ ) in a $100 \mathrm{ml}$ flask and shaken at a temperature of $37^{\circ} \mathrm{C}$. After 15, 30, 60 and 120 min of incubation, samples of $0.1 \mathrm{ml}$ were withdrawn for analysis.

Process with immobilized cells in shake flask. Immobilized cells ( $2 \mathrm{~g}$ biocatalysts containing $1 \mathrm{~g}$ of wet biomass) were washed with distilled water and introduced into the shaken $100 \mathrm{ml}$ flasks with $20 \mathrm{ml}$ production media. The biosynthesis process was conducted as described above.

Continuous production of L-aspartic acid in bioreactors by immobilized cells. Water jacket column bioreactors with different working volumes, i.e.: $2 \mathrm{ml}$,
$20 \mathrm{ml}$ and $40 \mathrm{ml}$ were used. The substrate solution was passed through the column using a peristaltic pump. Both the medium and biocatalyst bed were kept at the same selected temperature.

Aspartic acid analysis. To estimate the amount of L-aspartic acid, HPLC was applied using a column 250-4 Lichrospher ${ }^{\mathrm{TM}}$ 100RP-18 (Merck) and Waters fluorescence detector, type 474 . The details of the analytical procedure were described in a previous study (Papierz et al., 2007).

\section{Results}

Immobilization procedure optimization. In preliminary trials of immobilization of E. coli cells using mutant B-715 the bacterial cells were immobilized as chitosan pellets of $1.5-2.0 \mathrm{~mm}$ diameter using three cross-linking reagents: sodium hexametaphosphate, sodium ortophosphate or penta-sodium triphosphate. In the optimum immobilization procedure, $5 \%$ chitosan sol containing E. coli cells was reacted with $4 \%$ hexametaphosphate solution for a duration of approximately $30 \mathrm{~min}$. The effect of the kind of phosphate ions used, their concentration and the time of pellet cross-linking on the activity and mechanical stability of the biocatalysts was investigated, and for further study, the recombinant cells of $E$. coli $\mathrm{P} 1$ were immobilized with $5 \%$ chitosan sol cross-linking $4 \%$ sodium hexametaphosphate solution for $15-45 \mathrm{~min}$ as this is the best means of cell immobilization.

During the recombinant $E$. coli P1 cell immobilization process, some difficulties with obtaining a homogeneous suspension of the cells in chitosan sol were observed. The biomass of the recombinant was sticky and stringy and the obtained pellets were irregular, with varying diameters. An irregular shape of the immobilized biocatalysts (Fig. 1) was unfavourable for packing them into a bioreactor. Those difficulties can influence the quality of the study and the reliability of the results obtained. With the aim of eliminating those difficulties, we examined the effect of components within the medium used for bacterial multiplication, and added a surface-active substance (surfactant) for the immobilization of recombinant cells. Two variants of the FF medium (for multiplication) were applied: a) with the previously) determined amount of Yeast Extract (rich medium - FF20), b) with half the previously determined amount of Yeast Extract (poor medium - FF10). The activation of biomass was carried out for 24 hours at $37^{\circ} \mathrm{C}$ in two activation media: a) without Tween 80 , b) with added Tween 80 . The application of the poor medium for the multiplication of recombinant E. coli P1, followed by the addition of surfactant for cell activation, caused easier 

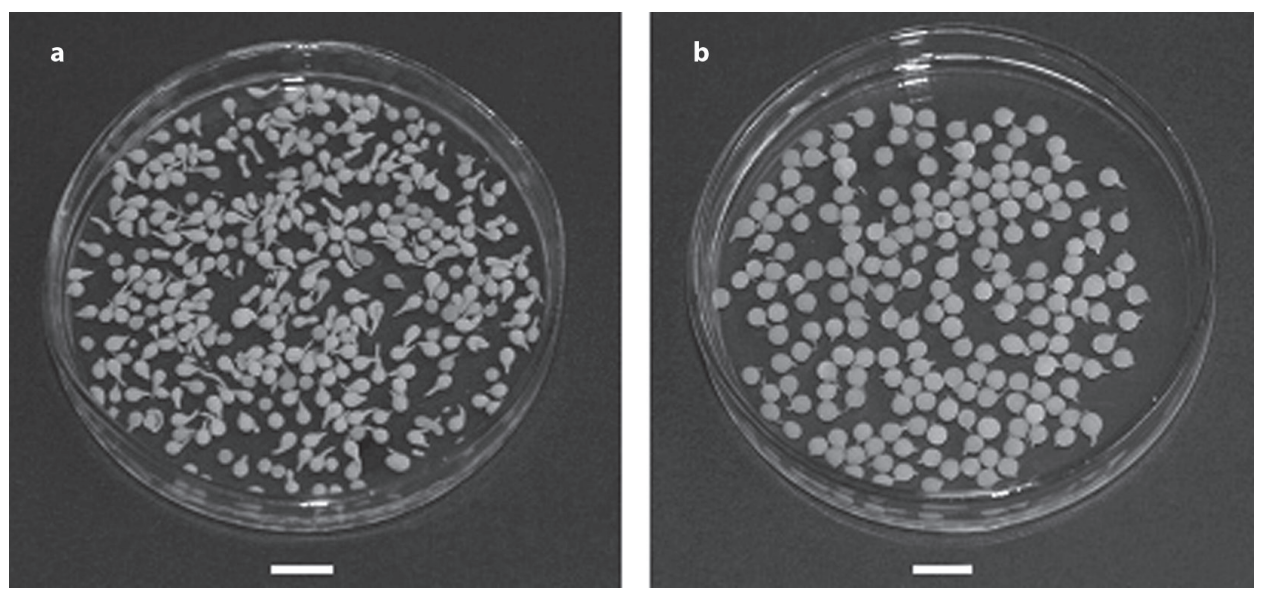

Fig. 1. E. coli P1 cells immobilized in chitosan gel: a) in rich medium without surfactant, b) in poor medium with surfactant.

immobilization and more effective L-aspartic acid biosynthesis (Fig. 2).

Activity of immobilized biocatalyst. Bacteria were cultivated and activated as described in Materials and Methods. The active biomass was divided into two parts. One part was used directly for the L-aspartic acid biosynthesis process in cell suspension; the second part was immobilized as described above. $1 \mathrm{~g}$ of intact cells or $2 \mathrm{~g}$ of immobilized cells were introduced into $20 \mathrm{ml}$ of the productive medium in $100 \mathrm{ml}$ flasks and shaken at a temperature of $37^{\circ} \mathrm{C}$. After $15 \mathrm{~min}$ of incubation, the samples were taken for analysis in order to estimate an initial (i.e. maximum) process rate for both preparations. The immobilized cells were almost $60 \%$ less active than the intact cells.

Effect of temperature. It is common knowledge that the rate of any biochemical process depends on its temperature; the rate increasing steadily as the temperature increases, up to the level at which enzymes are inactivated. Immobilization of the cells or enzymes can affect the thermal stability of biocatalysts. Exothermic

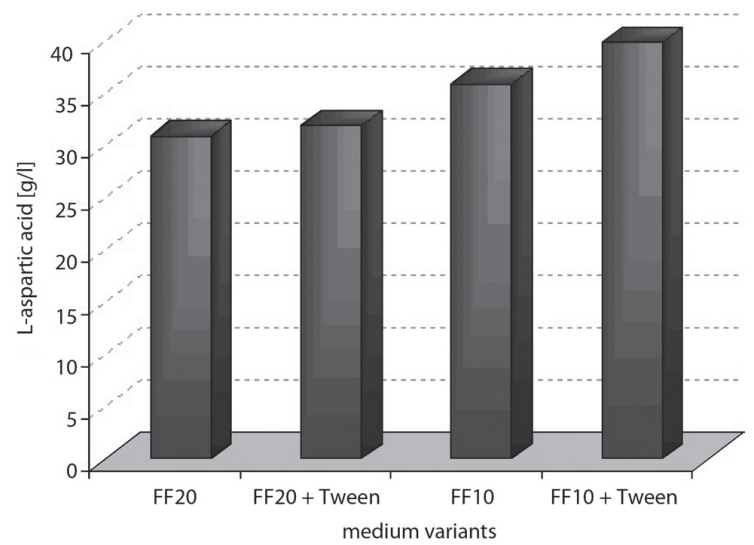

Fig. 2. Effect of multiplication and activation of bacteria on L-aspartic acid biosynthesis by immobilized cells E. coli P1. reactions, such as L-aspartic acid biosynthesis, complicate temperature optimization in long-term, largescale bioreactor processes. There are different optimum temperature values for highest reaction rate in a batch short-term process and in a long-term continuous process. Biosynthesis in shaking flasks at the growth-optimum temperature $37^{\circ} \mathrm{C}$ and much higher temperatures: $48,50,52,54$ and $56^{\circ} \mathrm{C}$ was studied. In a short (up to 2 hours) test, biocatalyst activity increased together with an increase in temperature, obtaining a maximum at 54 and $56^{\circ} \mathrm{C}$ (Fig. 3). In the next experiment the activity of newly-immobilized cells at $56^{\circ} \mathrm{C}$ for a 72 -hour bioreactor run was investigated with a substrate flow rate of $44 \mathrm{ml} / \mathrm{h}$. In this process the conversion of ammonium fumarate to L-aspartic acid decreases during the first day by nearly one-third (Fig. 4). On the basis of this result

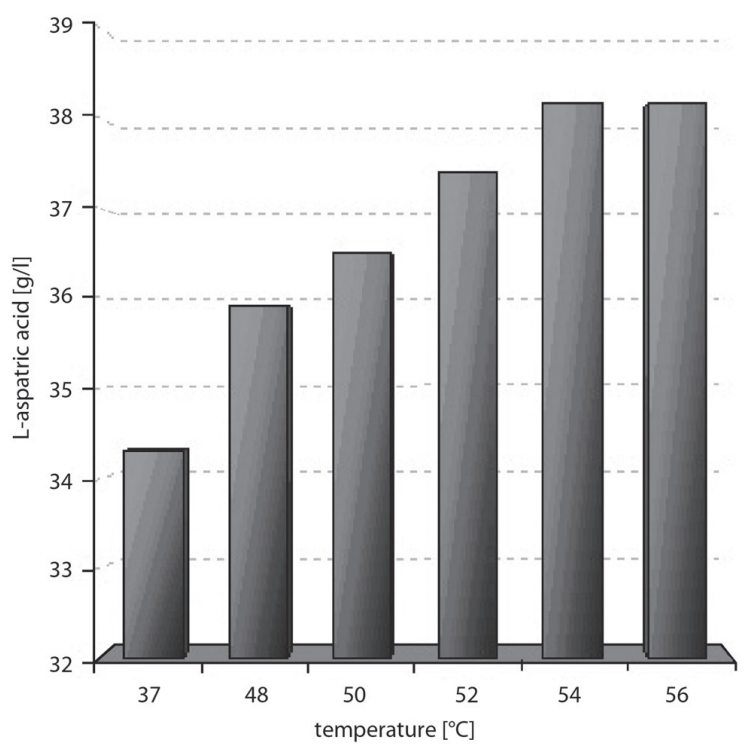

Fig. 3. Effect of temperature on biosynthesis of L-aspartic acid by immobilized cells E. coli $\mathrm{P} 1$. 


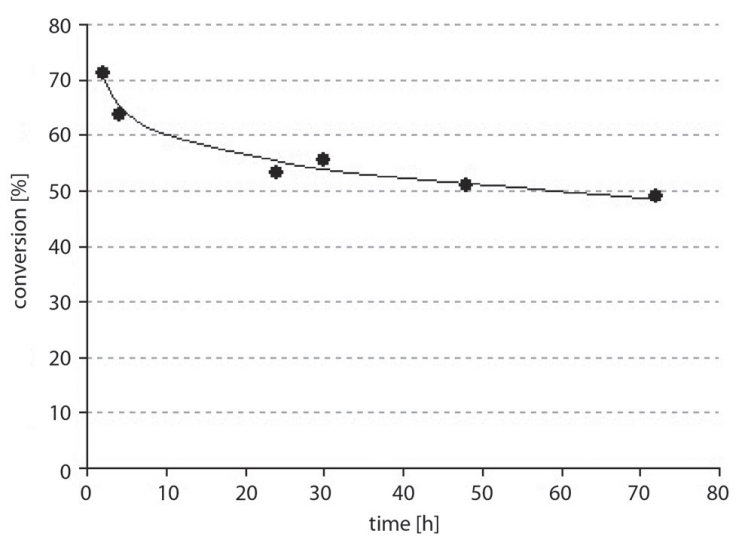

Fig. 4. Decrease of conversion of ammonium fumarate to $\mathrm{L}$-aspartic acid by immobilized cells $E$. coli $\mathrm{P} 1$ during 3 days test in $56^{\circ} \mathrm{C}$.

a new process was conducted at temperatures of $37^{\circ} \mathrm{C}$ and $40^{\circ} \mathrm{C}$. During a 603 -hour operation of the bioreactor, biocatalyst activities at both temperatures were at similar levels (about 55\% conversion). For further experiments, temperatures in the range $37-40^{\circ} \mathrm{C}$ was applied.

The effect of ammonium fumarate concentration. The aim of evolving technology is to obtain the highest possible concentration of a given product. In one-step enzymatic reaction, such as L-aspartic acid biosynthesis, it is possible to obtain this result by increasing substrate concentration. The effect of production medium ammonium fumarate concentration on L-aspartic acid biosynthesis was investigated in three bioreactors running in parallel. Every bioreactor was supplied $(100 \mathrm{ml} / \mathrm{h})$ with different concentration of ammonium fumarate, i.e.: $1.0 \mathrm{~mol} / \mathrm{l}(150 \mathrm{~g} / \mathrm{l}), 1.2 \mathrm{~mol} / \mathrm{l}(180 \mathrm{~g} / \mathrm{l})$ and $1.5 \mathrm{~mol} / \mathrm{l}(225 \mathrm{~g} / \mathrm{l})$ in substrate solution. The initial rate of ammonium fumarate to L-aspartic acid conversion in every bioreactor was over $50 \%$. However, over the next 40 days, a decrease in conversion yield, dependent on substrate concentration, was observed. In the days that followed, productivity was stable in every bioreactor; however, the best results were achieved with a substrate concentration of $1 \mathrm{~mol} / \mathrm{l}$ (Fig. 5).

After the continuous process had run for 603 hours in the bioreactors, the biocatalyst preparations were removed, and their activities in shaking flasks in fresh ammonium fumarate solution of $1 \mathrm{~mol} / \mathrm{l}$ were investi-

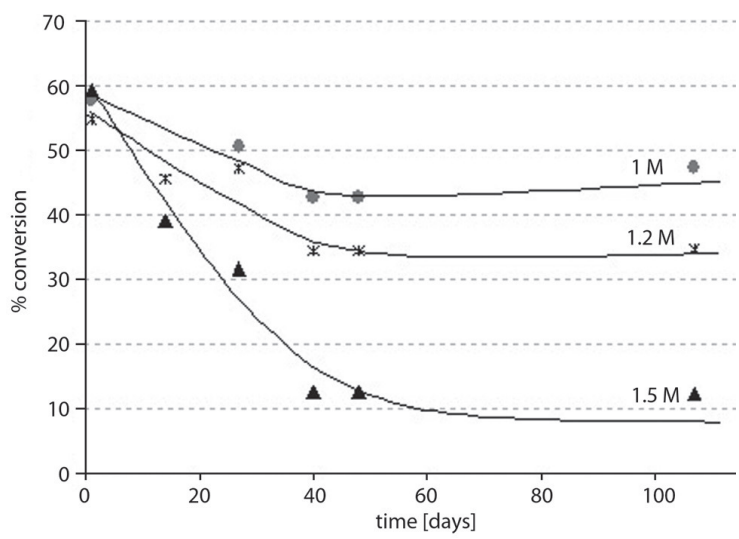

Fig. 5. Effect of ammonium fumarate concentration on continuous production of L-aspartic acid in a column bioreactor with immobilized cells E. coli P1.

gated as a short-term experiment for residual activity of biocatalysts estimation. An experiment with newlyimmobilized cells was conducted as the control. The highest activity was observed for biocatalyst previously working in substrate solution of $1 \mathrm{~mol} / \mathrm{l}$ (Fig. 5). The use of higher concentrations of ammonium fumarate during a long-term continuous process resulted in biocatalyst inactivation.

Continuous production of L-aspartic acid. Appropriate quantities of immobilized cells of E. coli P1 were placed into the three column bioreactors: A, B and C, as described in Table I. The conversion of ammonium fumarate to L-aspartic acid in continuous process at a substrate solution flow rate of below $100 \mathrm{ml} / \mathrm{h}$ in these reactors is shown in figure 6 . In the first experiment carried out in bioreactor A, a fresh biocatalyst was used after cell immobilization. In bioreactor A with $43 \mathrm{ml}$ of biocatalyst ( $3.8 \mathrm{~g}$ dry mass of $E$. coli $\mathrm{P} 1$ cells) production medium was passed through at flow rates $r_{z}$ from 5 to $858 \mathrm{ml} / \mathrm{h}$ at $37^{\circ} \mathrm{C}$ (Table II, Fig. 6). The highest conversion rate, over $95 \%$, was obtained at a substrate flow rate of $r_{z}=53-136 \mathrm{ml} / \mathrm{h}$. Increasing the substrate flow rate to over $136 \mathrm{ml} / \mathrm{h}$, a permanent decrease in substrate to product conversion ratio was observed. At a maximum flow rate of $858 \mathrm{ml} / \mathrm{h}$, the conversion ratio decreased below $50 \%$.

It is possible to assume that the freshly prepared biocatalyst used in this experiment, despite earlier activa-

Table I

Characteristics of bioreactors A, B and C

\begin{tabular}{|c|c|c|c|c|}
\hline Bioreactor & $\begin{array}{c}\text { Volume } \\
\text { of a biocatalyst } \\
\text { bed }\left(\mathrm{V}_{\mathrm{z}}\right)[\mathrm{ml}]\end{array}$ & $\begin{array}{c}\text { Dry mass } \\
\text { of cells in } \\
\text { biocatalyst }[\mathrm{g}]\end{array}$ & $\begin{array}{c}\text { Height } \\
\text { of biocatalyst } \\
\text { bed }\left(\mathrm{H}_{\mathrm{z}}\right)[\mathrm{cm}]\end{array}$ & $\mathrm{H}_{\mathrm{z}} / \mathrm{V}_{\mathrm{z}}$ ratio \\
\hline A & 43.0 & 3.80 & 15.0 & 0.35 \\
\hline B & 10.0 & 0.83 & 3.5 & 0.35 \\
\hline C & 1.3 & 0.15 & 4.0 & 3.10 \\
\hline
\end{tabular}




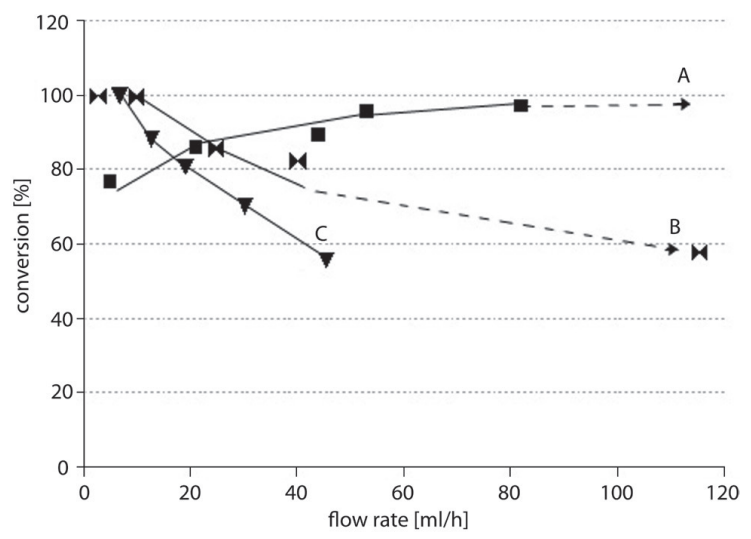

Fig. 6. Effect of substrate flow rate on conversion of ammonium fumarate to L-aspartic acid in bioreactors A, B and C.

tion, did not achieve its maximum activity. It could be that further cell activation occurred in the biocatalyst bed through the initial period of the biosynthesis process in the bioreactor. In the next experiment, freshly prepared pellets of biocatalyst were placed into production medium for 3 days before they were used for continuous process in bioreactor B. This biocatalyst preparation stage may well have caused further reduction of the diffusion barrier for substrate and product through the external envelopes of the cells. As the result, the maximum conversion ratio of nearly $100 \%$ was achieved in bioreactor B during the initial period of the process for a flow rate $r_{z}=2.8-10.0 \mathrm{ml} / \mathrm{h}$. The productivity of the biocatalyst in this experiment was $0.4-1.6 \mathrm{~g} / \mathrm{g} / \mathrm{h}$ (Table III).

Table II

Effect of substrate medium flow rate through bioreactor A during L-aspartic acid biosynthesis

\begin{tabular}{|c|c|c|c|c|}
\hline $\begin{array}{c}\text { Flow } \\
\text { rate } \\
{[\mathrm{ml} / \mathrm{h}]}\end{array}$ & $\begin{array}{c}\text { Liquid hour } \\
\text { space velocity } \\
\text { LHSV }\end{array}$ & $\begin{array}{c}\text { L-aspartic } \\
\text { acid } \\
{[\mathrm{g} / \mathrm{l}]}\end{array}$ & $\begin{array}{c}\text { Productivity } \\
{[\mathrm{g} / \mathrm{g} / \mathrm{h}]}\end{array}$ & $\begin{array}{c}\text { Conversion } \\
{[\%]}\end{array}$ \\
\hline 5 & 0.1 & 102.0 & 0.1 & 76.7 \\
\hline 21 & 0.5 & 113.3 & 0.6 & 85.9 \\
\hline 44 & 1.0 & 118.0 & 1.5 & 89.4 \\
\hline 53 & 1.2 & 124.0 & 1.7 & 95.7 \\
\hline 82 & 1.9 & 129.3 & 2.8 & 97.2 \\
\hline 136 & 3.1 & 126.7 & 4.5 & 95.1 \\
\hline 162 & 3.8 & 119.3 & 5.0 & 89.8 \\
\hline 192 & 4.5 & 119.3 & 6.0 & 89.8 \\
\hline 258 & 6.0 & 116.7 & 8.1 & 87.9 \\
\hline 312 & 7.3 & 110.7 & 9.1 & 83.1 \\
\hline 360 & 8.4 & 108.7 & 10.3 & 81.6 \\
\hline 675 & 15.7 & 71.0 & 12.6 & 53.3 \\
\hline 858 & 20.0 & 62.7 & 14.1 & 47.1 \\
\hline
\end{tabular}

An important parameter introduced in this work, according to Mukouyama and Komatsuzaki (2001), was the ratio of the bioreactor height to the bioreactor volume $\left(\mathrm{H}_{\mathrm{zl}} \mathrm{V}_{\mathrm{z}}\right)$. In both experiments for different biocatalyst volumes in bioreactor $\mathrm{A}$ and $\mathrm{B}$, the same ratio $\mathrm{H}_{z /} \mathrm{V}_{\mathrm{z}}=0.35$ was maintained. In the next experiment bioreactor $\mathrm{C}$ was used with a biocatalyst bed height of $4 \mathrm{~cm}$ and working volume of $1.3 \mathrm{ml} ; \mathrm{H}_{\mathrm{z}} / \mathrm{V}_{\mathrm{z}}=3.1$. The maximum conversion ratio of over $99 \%$ for the low flow rate of $6.8 \mathrm{ml} / \mathrm{h}$, was achieved. The productivity of the biocatalyst in this experiment was $6 \mathrm{~g} / \mathrm{g} / \mathrm{h}$. The increased substrate solution flow rate through bioreactor $\mathrm{C}$ resulted in the same decrease of conversion rate as in bioreactors $\mathrm{A}$ and $\mathrm{B}$, however with a lower ratio (Table IV).

\section{Discussion}

For L-aspartic acid biosynthesis, the high production cells of Escherichia coli were immobilized in chitosan gel using a technique developed in our laboratory. In the process of cell immobilization it is crucial to obtain a homogenous suspension of bacterial cells. In the case of the immobilization of recombinant E. coli $\mathrm{P} 1$, the addition of the surfactant Tween 80 to the medium for biomass cultivation was necessary. This

Table III

Effect of substrate medium flow rate through bioreactor B during L-aspartic acid biosynthesis

\begin{tabular}{|c|c|c|c|c|}
\hline $\begin{array}{c}\text { Flow } \\
\text { rate } \\
{[\mathrm{ml} / \mathrm{h}]}\end{array}$ & $\begin{array}{c}\text { Liquid hour } \\
\text { space velocity } \\
\text { LHSV }\end{array}$ & $\begin{array}{c}\text { L-aspartic } \\
\text { acid } \\
{[\mathrm{g} / \mathrm{l}]}\end{array}$ & $\begin{array}{c}\text { Productivity* } \\
{[\mathrm{g} / \mathrm{g} / \mathrm{h}]}\end{array}$ & $\begin{array}{c}\text { Conversion } \\
{[\%]}\end{array}$ \\
\hline 2.8 & 0.3 & 132.6 & 0.4 & 99.7 \\
\hline 10.0 & 1.0 & 132.3 & 1.6 & 99.5 \\
\hline 24.8 & 2.5 & 113.8 & 3.4 & 85.6 \\
\hline 40.2 & 4.0 & 109.5 & 5.3 & 82.3 \\
\hline 115.5 & 11.6 & 76.9 & 10.6 & 57.8 \\
\hline 123.0 & 12.3 & 75.1 & 11.1 & 56.5 \\
\hline
\end{tabular}

* productivity as grams of $\mathrm{L}$-aspartic acid calculated as $1 \mathrm{~g}$ dry weight of biomass per 1 hour $[\mathrm{g} / \mathrm{g} / \mathrm{h}]$

Table IV

Effect of substrate medium flow rate through bioreactor $\mathrm{C}$ during L-aspartic acid biosynthesis

\begin{tabular}{|c|c|c|c|c|}
\hline $\begin{array}{c}\text { Flow } \\
\text { rate } \\
{[\mathrm{ml} / \mathrm{h}]}\end{array}$ & $\begin{array}{c}\text { Liquid hour } \\
\text { space velocity } \\
\text { LHSV }\end{array}$ & $\begin{array}{c}\text { L-aspartic } \\
\text { acid } \\
{[\mathrm{g} / \mathrm{l}]}\end{array}$ & $\begin{array}{c}\text { Productivity* } \\
{[\mathrm{g} / \mathrm{g} / \mathrm{h}]}\end{array}$ & $\begin{array}{c}\text { Conversion } \\
{[\%]}\end{array}$ \\
\hline 6.8 & 5.2 & 132.8 & 6.0 & 99.8 \\
\hline 12.8 & 9.8 & 117.3 & 10.0 & 88.2 \\
\hline 19.2 & 14.8 & 107.5 & 14.0 & 80.8 \\
\hline 30.4 & 23.4 & 93.1 & 18.7 & 70.0 \\
\hline 45.6 & 35.1 & 74.1 & 22.7 & 55.7 \\
\hline
\end{tabular}

* productivity as grams of L-aspartic acid calculated as $1 \mathrm{~g}$ dry weight of biomass per 1 hour $[\mathrm{g} / \mathrm{g} / \mathrm{h}]$ 
surfactant facilitated the immobilization of the recombinant cells; as mentioned above, their biomass was sticky and difficult to homogenize without it. Among three reagents, sodium orthophosphate, penta-sodium triphosphate and sodium hexametaphosphate, the final one was selected as the best cross-linking agent. Chibata et al. (1974) and Sato et al. (1975) have suggested the use of polyacrylamide gel; however, it is mechanically unstable and, following polymerization, some toxic monomer (acrylamide) usually remains inside the gel. Sato et al. (1979) and Umemura et al. (1984) have immobilized the cells and enzymes for L-aspartic acid production in $\kappa$-carrageenan gel. The main disadvantage of this method is the high temperature, $45-55^{\circ} \mathrm{C}$, which is required for $\kappa$-carrageenan sol preparation. Very popular for biocatalyst preparation for various biochemical reactions is an alginate gel, which is cheap and extremely easy to prepare. We tested the alginate gel containing active E.coli cells for conversion of ammonium fumarate to L-aspartic acid (Chmiel et al., data not published). However, alginate beds proved very unstable in the process conditions.

It is commonly known that any immobilization technique causes reduction in the initial activity of intact free cells or enzymes. In the case of our immobilized biocatalyst, the activity reduction was about $60 \%$, however the main aim of cell or enzyme immobilization is in stabilizing the biocatalyst for long-term use in multi-repeated batch or continuous processes.

It is necessary to optimize the basic reaction parameters for the newly immobilized biocatalyst. The control of temperature during L-aspartic acid biosynthesis is extremely important because a considerable amount of heat is produced during the process. Conducting the process at a higher temperature may reduce the necessary cooling of the biocatalyst bed, thereby reducing the cost of production. In our work, the increase of temerature from 37 to $56^{\circ} \mathrm{C}$ causes a significant increase in the rate of L-aspartic acid biosynthesis in shortterm experiments. However, after 24, 49 and 72 hours, the cell activity has decreased to $75 \%, 72 \%$ and $69 \%$ respectively. The thermal instability of the immobilized L-aspartic acid producing E. coli cells was described earlier (Chibata et al., 1974; Tosa et al., 1974). The aspartase instability in E. coli cells has been described in patents (Mukouyama et al., 2000; Mukouyama et al., 2001). The thermal stability of biocatalysts was tested at 37 and $40^{\circ} \mathrm{C}$ in long-term experiments over 603 hours. The activity of the biocatalyst was roughly equal at both temperatures and after 25 days, had decreased by only about $3-5 \%$. In comparison with published data (Chibata et al., 1974; Tosa et al., 1974) immobilized recombinant E. coli P1 cells show a higher thermal stability, and their maximum activity was attained at a temperature approximately $4^{\circ} \mathrm{C}$ higher in our studies.
Substrate concentration is another important process parameter influencing both the reaction rate and product concentration. In our study, the optimum ammonium fumarate concentration was $1.0 \mathrm{M}$ what was agreement with other publications. Increases of substrate concentration to 1.2 and $1.5 \mathrm{M}$ decreased the efficiency of the continuous process and caused additional biocatalyst inactivation of about $8-13 \%$ and $13-28 \%$ respectively.

In accordance with literature (Mukouyama and Komatsuzaki, 2000; Mukouyama and Komatsuzaki, 2001) the process of L-aspartic acid biosynthesis is profitable for a conversion rate over $90 \%$, which was obtained in our experiment at a flow rate of $r_{z}<162 \mathrm{ml} / \mathrm{h}$ for bioreactor A. In those conditions, the productivity of L-aspartic acid, defined as mass of product per cell dry mass in biocatalyst per time unit, was $4.5 \mathrm{~g} / \mathrm{g} / \mathrm{h}$. For a description of the efficiency of the continuous $\mathrm{L}$-aspartic acid production process, the parameter liquid hour space velocity (LHSV, i.e. $\mathrm{ml} / \mathrm{ml} / \mathrm{h}$ ) or simply space velocity (SV) was proposed by Mukouyama and Komatsuzaki (2001). It is defined as the volume of feeding substrate passed per volume of catalyst bed in bioreactor per one hour. Analyzing the LHSV, it is easy to compare continuous processes conducted in different bioreactors. The maximum conversion yield obtained for the process in bioreactor A was $97 \%$ for a substrate solution flow rate of $82 \mathrm{ml} / \mathrm{h}$ through the bioreactor. However LHSV for these conditions was 1.9 only. A dramatic decrease in the conversion ratio was observed in bioreactor A at LHSV over 3.1 and in bioreactor B at LHSV over 1.0 (Fig. 7).

As in both experiments for different biocatalyst volumes in bioreactor $\mathrm{A}$ and $\mathrm{B}$, the same ratio $\mathrm{H}_{z /} \mathrm{V}_{\mathrm{z}}=0.35$ was maintained, in the next experiment bioreactor $\mathrm{C}$ was used with $\mathrm{H}_{z} / \mathrm{V}_{z}=3.1$. For the liquid hour space velocity $=5.2$ a maximum conversion ratio of over $99 \%$ and productivity of $6 \mathrm{~g} / \mathrm{g} / \mathrm{h}$ in this bioreactor was achieved. The increased substrate solution flow rate through bioreactor $C$ resulted in the same decrease of conversion rate as in bioreactors $\mathrm{A}$ and $\mathrm{B}$, however with a lower ratio. A conversion rate of about $90 \%$ was obtained even for the high LHSV value of about 10 (Fig. 7).

Generally, the best result of the L-aspartic acid biosynthesis process was achieved in bioreactor $\mathrm{C}$, which has the lowest volume of biocatalyst $(1.3 \mathrm{ml})$. For the whole range of the tested flow rates, the substrate to product conversion ratio did not decrease below $50 \%$. By extrapolating the experimental results, it is estimated that a conversion level equal to $50 \%$ can be achieved at LHSV values up to about 40 (Fig. 7). Analysis of the relationships between conversion ratio and LHSV and between bioreactor productivity (calculated by biomass unit) and LHSV shows also the importance of the rela- 


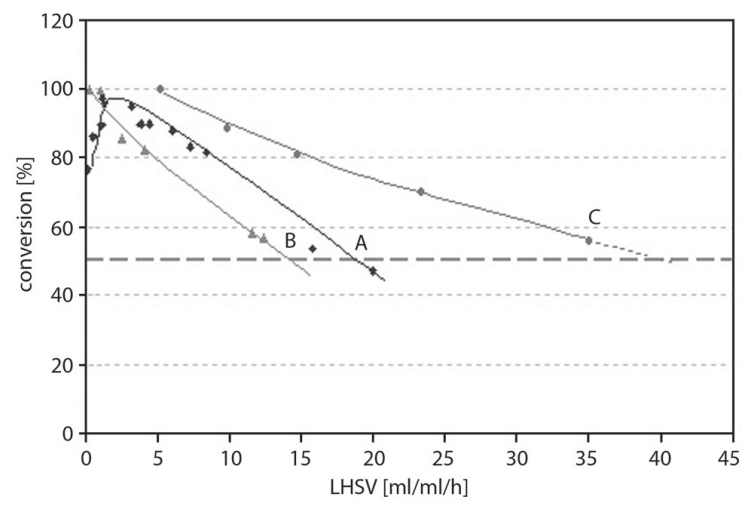

Fig. 7. Effect of liquid hour space velocity of production through bioreactors $\mathrm{A}, \mathrm{B}$ and $\mathrm{C}$ on ammonium fumarate conversion to L-aspartic acid.

tionship $\mathrm{H}_{\mathrm{z}} / \mathrm{V}_{\mathrm{z}}$ in bioreactors (Fig. 7 and 8). The higher this relationship, the more effective $\mathrm{L}$-aspartic acid biosynthesis is in continuous process. The substrate to product conversion rate of over $90 \%$ in bioreactors B and A with similar $\mathrm{H}_{\mathrm{z}} / \mathrm{V}_{\mathrm{z}}=0.35$, was achieved with the $\mathrm{L}$-aspartic acid productivity below $3.4 \mathrm{~g} / \mathrm{g} / \mathrm{h}$ and below $5.0 \mathrm{~g} / \mathrm{g} / \mathrm{h}$ respectively. In bioreactor $\mathrm{C}$ with $\mathrm{H}_{\mathrm{z}} / \mathrm{V}_{\mathrm{z}}=3.1$, i.e. 9 times higher than in bioreactors $\mathrm{A}$ and $\mathrm{B}$, this yield limit (90\%) was achieved with a significant higher productivity of nearly $10.0 \mathrm{~g} / \mathrm{g} / \mathrm{h}$. These results correspond to the literature data of Tosa et al. (1973) and Mukouyama and Komatsuzaki (2001) who reported a positive correlation between bioreactor column height (length) and L-aspartic acid formation efficiency.

\section{Conclusions}

For the development of L-aspartic acid biosynthesis technology, the new high yielding recombinant E. coli P1 was constructed (Gadomska et al., 2007). In this paper the new immobilization method of the E. coli P1 cells in chitosan gel was standardized. It was the starting point for laboratory process elaboration using column bioreactors characterized by different volumes and different height to volume ratios. Optimization of the biosynthesis process was based on both these parameters and the substrate flow rate through the bioreactors. Two factors were critical for the bioreactor achieving optimum production capacity: Firstly, sufficient preliminary activation of the biocatalyst through its incubation in substrate solution before its use for biosynthesis process, and secondly, optimal substrate flow rate through biocatalyst bed during the continuous process of L-aspartic acid. Two parameters, i.e. the biocatalyst bed height to volume ratio $\left(\mathrm{H}_{\mathrm{z}} / \mathrm{V}_{\mathrm{z}}\right)$ and liquid hour space velocity $(\mathrm{ml} / \mathrm{ml} / \mathrm{h})$ were used as essential criteria for the process optimization, i.e. maximum of

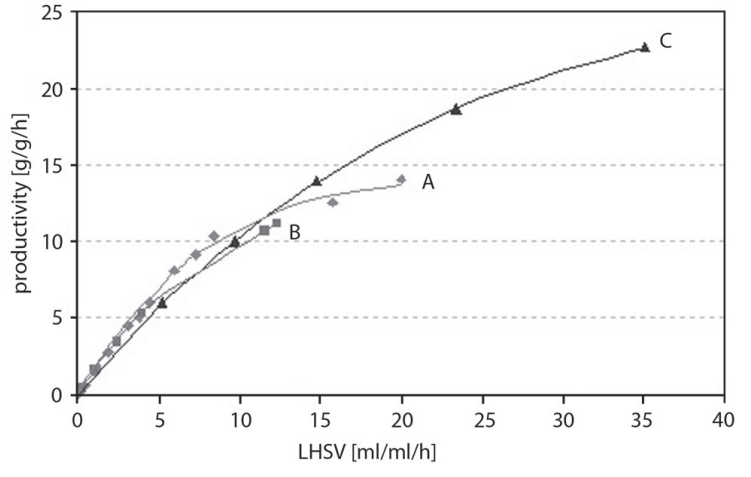

Fig. 8. Effect of liquid hour space velocity of production through bioreactors $\mathrm{A}, \mathrm{B}$ and $\mathrm{C}$ on biocatalyst bed productivity.

yield (\%) and maximum productivity, defined as mass of product per mass of biocatalyst per time unit $(\mathrm{g} / \mathrm{g} / \mathrm{h})$. In bioreactors $A$ and $B$ with an $\mathrm{H}_{z} / \mathrm{V}_{z}$ of 0.35 , the maximum substrate to product conversion rate was $95.7 \%$ and productivity $1.7 \mathrm{~g} / \mathrm{g} / \mathrm{h}$ with an LHSV of 1.2 for bioreactor $\mathrm{A}$, and conversion over $99 \%$ and productivity $0.4-1.6 \mathrm{~g} / \mathrm{g} / \mathrm{h}$ with an LHSV of $0.3-1$ for bioreactor B. However in bioreactor $\mathrm{C}$ with $\mathrm{H}_{\mathrm{z}} / \mathrm{V}_{\mathrm{z}}$ of 3.1, i.e. 9 times higher than in bioreactors $\mathrm{A}$ and $\mathrm{B}$, the maximum yield was $99.8 \%$, with significant higher productivity, $6 \mathrm{~g} / \mathrm{g} / \mathrm{h}$, for a much higher LHSV of 5.2 have been achieved. In conclusion, it is clear that the height to volume ratio of a biocatalyst bed (and column bioreactor) is a key factor in the process development of L-aspartic acid biosynthesis, and the liquid hour space velocity (LHSV) is an important index of the optimization procedure.

\footnotetext{
Acknowledgements

The authors are grateful to George Gasyna and Edward Lowczynski for helpful writing this paper.
}

\section{Literature}

Chibata I., T. Tosa and T. Sato. 1974. Immobilized aspartase-containing microbial cells: preparation and enzymatic properties. Appl. Microbiol. 27: 878-885.

Chibata I., T. Tosa and T. Sato. 1985. Aspartic acid. Comprehensive Biotechnology, vol. 3: 633-640, Moo-Young M. (ed.) Pergamon Press, Oxfort-New York.

Fusee M.C., W.E. Swann and G.J. Calton. 1981. Immobilization of Escherichia coli cells containing aspartase activity with polyurethane and its application for L-aspartic acid production. Appl. Environ. Microbiol. 42: 672-676.

Gadomska G., A. Płucienniczak and A. Chmiel. 2007. Recombinant strains of Escherichia coli for L-aspartic acid. Pol. J. Microbiol. 56: 77-82

Kawabata N., S. Nishimura and T. Yoshimura. 1990. New method of immobilization of microbial cells by capture on the surface of insoluble pyridinium-type resin. Biotechnol. Bioeng. 35: 1000-1005. 
Lee C. K. and J. Hong. 1988. Membrane reactor coupled with electrophoresis for enzymatic production of aspartic acid. Biotechnol. Bioeng. 32: 647-654.

Mukouyama M., Masaharu, Komatsuzaki S. and Satomi. 2000. Process for production of L-aspartic acid. United States Patent. 6: 150,142. Mukouyama M. and S. Komatsuzaki. 2001. Method for producing L-aspartic acid. United States Patent: 6: 214,589.

Papierz M., G. Gadomska, B. Sobierajski and A. Chmiel. 2007. Selection and activation of Escherichia coli strains for L-aspartic acid biosynthesis. Polish Journal of Microbiology 56: 71-76.

Sato T., T. Mori, T. Tosa and I. Chibata. 1975. Engineering analysis of continuous production of L-aspartic acid by immobilized Escherichia coli cells in fixed beds. Biotech. Bioeng. 17: 1797-1804.
Sato T., Y. Nishida, T. Tosa, and I. Chibata. 1979. Immobilization of Escherichia coli cells containing aspartase activity with $\kappa$-carrageenan: enzymic properties and application for L-aspartic acid production. Biochim. Biophys. Acta 570: 179-186.

Tosa T., T. Sato, T. Mori, Y. Matuo and I. Chibata. 1973. Continious production of L-aspartic acid by immobilized aspartase. Biotechnol. Bioeng. 15: 69-84.

Tosa T., T. Sato, T. Mori and I. Chibata. 1974. Basic studies for continous production of L-aspartic acid by immobilized Escherichia coli cells. Appl. Microbiol. 27: 886-889.

Umemura I., S. Takamatsu, S. Sato, T. Tosa and I. Chibata. 1984. Improvement of production of L-aspartic acid using immobilized microbial cells. Appl. Microbiol. Biotechnol. 20, 291-295. 